\title{
CONTENTS OF VOLUME 41
}

RAFIKUL ALAM, REKHA P. KULKARNI and BALMOHAN V. LIMAYE: Accelerated spectral refinement. Part I: Simple eigenvalue

J. E. ALDRIDGE: See G. E. PRINCE

I. ALI and S. KALLA: A generalized Hankel transform and its use for solving certain partial differential equations

MALCOLM ANDERSON: Near-field expansion of the metric due to a cosmic string

MALCOLM R. ANDERSON: See TZE-CHUEN TOH

K. BALACHANDRAN: See R. SUBRAMANIAM

J. C. BARTON and C. J. ELIEZER: On pursuit curves

CHARLES BU: Forced cubic Schrödinger equation with Robin boundary data: continuous dependency result

G. B. BYRNES: See G. E. PRINCE

REYNALDO CASTILLO: See WAI KIN CHAN

P. CERONE and A. SOFO: Summing series arising from integro-differential-difference equations

WAI KIN CHAN, REYNALDO CASTILLO and KING FAI LAI: Foliations in supergravity

E. W. M. CHOW and A. W.-C. LUN: Apparent horizons in vacuum Robinson-Trautman spacetimes

PAULINE COOLEN-SCHRIJNER, ANDREW HART and PHIL POLLETT: Quasistationarity of continuous-time Markov chains with positive drift

N. ELEZOVIĆ, M. MATIĆ, C. E. M. PEARCE and J. PEČARIĆ: On two lemmas of Brown and Shepp having application to sum sets and fractals, III

C. J. ELIEZER: See J. C. BARTON

J. F. Q. FERNANDES and A. W.-C. LUN: Integrability conditions for the Bianchi identities as transformations in Schwarzschild space-time

L. K. FORBES: See A. J. KOERBER

HANG GAO and XUNJING LI: Necessary conditions for optimal control of elliptic systems

S. E. GODFREY: See G. E. PRINCE

J. R. GRAEF and C. QIAN: Global attractivity in differential equations with variable delays

ANDREW HART: See PAULINE COOLEN-SCHRIJNER

JACK HEIDEL and JOHN MALONEY: An analysis of a fractal Michaelis-Menten curve

JACK HEIDEL and JOHN MALONEY: When can sigmoidal data be fit to a Hill curve?

JACK HEIDEL: See JOHN MALONEY

L. D. HIRD, P. F. SIEW and S. WANG: A numerical solution to the flow between eccentric rotating cylinders with a slotted sleeve

S. KALLA: See I. ALI

HONG OH KIM and JONG HA PARK: The generalized Shannon system in wavelet space

JÜRGEN KLENK: Existence of stationary vacuum solutions of Einstein's equations in an exterior domain 
A. J. KOERBER and L. K. FORBES: An analysis of two and three dimensional unsteady withdrawal flows, using shallow water theory

REKHA P. KULKARNI: See RAFIKUL ALAM

KING FAI LAI: See WAI KIN CHAN

BALMOHAN V. LIMAYE: See RAFIKUL ALAM

HUAN-WEN LIU: An expansion of bivariate spline functions

Y. LIU and K. L. TEO: A bridging method for global optimization

XUNJING LI: See HANG GAO

A. W.-C. LUN: See D. A. PRAGER

A. W.-C. LUN: See E. W. M. CHOW

A. W.-C. LUN: See J. F. Q. FERNANDES

ANTHONY LUN: See PETER SZEKERES

O. D. MAKINDE: Extending the utility of perturbation series in problems of laminar flow in a porous pipe and a diverging channel

JOHN MALONEY, JACK HEIDEL and JOSIP PEC̆ARIĆ: A reverse Hölder type inequality for the logarithmic mean and generalizations

JOHN MALONEY: See JACK HEIDEL

JOHN MALONEY: See JACK HEIDEL

M. MATIĆ: See N. ELEZOVIĆ

A. NOURI: An Euler-Poisson system in plasmas

JONG HA PARK: See HONG OH KIM

C. E. M. PEARCE: See N. ELEZOVIĆ

JOSIP PEČARIĆ: See JOHN MALONEY

J. PEČCARIĆ: See N. ELEZOVIĆ

J. R. PHILIP: Instantaneous point source solutions in nonlinear diffusion with nonlinear loss or gain

PHIL POLLETT: See PAULINE COOLEN-SCHRIJNER

D. A. PRAGER and A. W.-C. LUN: Numerical integration of the axisymmetric RobinsonTrautman equation by a spectral method

G. E. PRINCE, J. E. ALDRIDGE, S. E. GODFREY and G. B. BYRNES: The separation of the Hamilton-Jacobi equation for the Kerr metric

C. QIAN: See J. R. GRAEF

CHANGZHENG QU: Reductions and exact solutions of some nonlinear partial differential equations under four types of generalized conditional symmetries

PENG SHI: Control of continuous-time systems with discrete jumps

P. F. SIEW: See L. D. HIRD

\section{A. SOFO: See P. CERONE}

R. SUBRAMANIAM and K. BALACHANDRAN: Existence of solutions of a class of stochastic Volterra integral equations with applications to chemotherapy

PETER SZEKERES and ANTHONY LUN: What is a shell-crossing singularity? 
K. L. TEO: See Y. LIU

TZE-CHUEN TOH and MALCOLM R. ANDERSON: Knots and gravity

E. O. TUCK: See L. H. WIRYANTO

S. WANG: See L. D. HIRD

SHIHONG WANG and ZUOYI ZHOU: Averaging of the Hamilton-Jacobi equation in infinite dimensions and an application

WANG WENDI and TANG CHUNLEI: Dynamics of a delayed population model with feedback control

WEICHUNG WANG: Final iterations in interior point methods - preconditioned conjugate gradients and modified search directions

DAVID L. WILTSHIRE: Dilaton black holes with a cosmological term

L. H. WIRYANTO and E. O. TUCK: An open-channel flow meeting a barrier and forming one or two jets

BRIAN YOUNG: Analysis and optimisation of looped water distribution networks

508

ZUOYI ZHOU: See SHIHONG WANG 